\title{
The Voiceless Women: A Study in Shivani’s Bhairavi: The Runaway
}

Megha Pant

Research Scholar

SGRR (PG) College, Dehradun

HNB Garhwal University

Srinagar, Uttarakhand, India

meghapant8090@gmail.com

\section{Abstract}

The term 'subaltern' incorporates the entire people that are subordinates in terms of class, caste, gender and rank, or in any other way. When it operates in terms of class, gender and caste, it is more psychological than physical. Antonio Gramsci coined the term subaltern to identify the cultural hegemony (According to Merriam Webster the word hegemony means the social, cultural, ideological, or economic influence exerted by a dominant group).

This paper endeavors to highlight the voiceless Marginalized women in Shivani's Bhairavi: The Runaway (a translation from the original Hindi text, Bhairavi rendered in English by Priyanka Sarkar). Shivani aka Gaura Pant was a very prolific and voluminous writer, she has many novels, short stories and essays to her credit. The English translation of her works give an insight into the deeper psychological understanding of women. Shivani's purpose is to give voice to the marginalized women in the society and to explore the discrimination order of caste, gender and class.

Keywords: Subaltern, Hegemony, Gender, Caste, Class and Discrimination.

India is basically a patriarchal society but some of the famous Indian Women writers are Kamla Markandaya, Dalip Kaur Tiwana, Shashi Deshpande, Anita Desai, Kiran Desai, Manju Kapoor, Mrinal Pande, Jaiwanti Dimri, Shivani and many more who have portrayed the 
real picture of Indian Women. Shivani Aka Gaura Pant won Padam Shri for her contribution to Hindi Literature in 1982. She analyzes the issues of class, caste and gender. Bhairavi: The Runaway is a feminist work which explains men's violence against women in a society. Shivani illustrates the subjective position of the voiceless women and their suppression, humiliation, sufferings, dilemmas, exploitation in her works.

The plight of a women and Marginalization in women's perspective is depicted well in work of a women writer. Shivani is a sensitive writer who has given a new perspective on the study of social reality of crucial issues related to women. Admittedly, one gets realistic glimpses of the lives of women through her novels.

Shivani was born on October 17, 1924, on Vijaya Dashmi in Rajkot, Gujarat. The English translation of her works gives an insight into the deeper psychological and understanding of women. Shivani's purpose was to give voice to the marginalized women in the society and to explore the discrimination orders of caste, gender and class. According to Mrinal Pande in forward of this novel:

In Bhairavi, the young protagonist Chandan becomes a prism through whom Shivani the writer observes, watches, recognizes, listens to all this. What happens to an innocent fatherless young girl when fate suddenly catapults her into a landscape totally exterior to her, not just once but again and again... (x).

This novel unfolds with the story of Rajrajeshwari. She was the mother of Chandan who is the protagonist of this novel. Rajrajeshwari who is commonly known as Raji in this novel was the daughter of Tiwari Ji. Raji had a school friend named Chandrika. Once when Chandrika visited Raji's home then Raji's mother came to know that Chandrika belongs to a lower caste. Raji's mother scolded to her daughter, "I 'll bury you alive if you continue fraternizing with her. That low caste girl with the airs of a princess!" (54). This statement shows the caste-based discrimination which prevailed within Indian society. Jaiwanti Dimri in her chapter titled 
"Rural Woman as Caste" in Images and Representation of the Rural Women: A Study of the Selected Novels of Indian Women Writers expresses her views on caste: "The trinity of caste, class and gender has been the locus of tension and conflict in India in terms of its socio- cultural history and the subsequent caste, class and gender specific representation in the literary and the social canon" (209, Dimri). The people who belonged to upper caste they did not want to have any relation with the people who belong to lower caste. Raji kept aside her mother's warning and started visiting Chandrika's home. When Chandrika's mother asked Raji about her father's name. She tells Mahimchandra Tiwari is my father. After hearing this name Rampyari Chandrika's mother questioned her where is your father now a days? and she reconciles her memories when she was a prostitute and Mahim was her lover. Rajrajeshwari started visiting her friend's home every day after school and comes close to Chandrika's brother named Kundan. Rampyari was aware about the relation between her son and Raji but she thinks:

What was the harm if her son got a high - born Brahmin girl? A daughter- in - law like Rajrajeshwari would be as precious to her as a plate of sesame. And that Brahmin would also be taught a lesson, the one who had kicked her glorious loveliness away on seeing the beautiful face of his wife. (60)

Raji and Kundan were busy in designing their future plans and on the other side it was a mystery how Tiwari Ji had found the news of his daughter's romance. "The daughter of a Kumaon Brahmin marrying a Kshatriya, and the son of his former mistress at that, he would kill his only daughter without a second thought before that could happen" (61). It shows his father was worried about his aura in society. "The Brahminical caste formulated the rules and strategically tried to maintain the hegemony of its caste in the form of a system of social hierarchies" (Dimri 210). So Raji and Kundan made a plan to run away from home but Raji's father caught them in Laal Kuan Railway station and dragged Raji to home and Kundan hide under the sugar cane pile to save his life. 
Tiwariji tried to hide this incident but he was not successful. Nobody was ready to forgive Raji for this act because she tried to run away with a prostitute's son. Mahim Tiwari wants to marry her daughter off as soon as possible so he requests his friend for a marriage bond but his friend replies: "Though poor, even we have a reputation to think of. We might be hungry but we will not eat the leftovers of a feast" (63).

Mahim Tiwari was ready to marry off her daughter to whomever he finds, be it a blind or a man without arms or legs. He wanted to remove the slur from his family's name. So Rajrajeshwari's father forced his daughter to marry a fifty-year-old childless widower to maintain their reputation in society. Rajrajeshwari's husband was a businessman as well as an alcoholic person. Tiwari fixed this wedding programme in Haldwani. When her husband came to know about her past, he imposed strict restrictions on her.

She never laughed or dressed up or applied make-up. She didn't even go to the veranda or the terrace, leave alone stepping outside the house. She never stood before the mirror. For his part, the jealous husband thought it prudent to fortify his fortress. He locked his wife in when he left for the shop (64).

Chandan was born after a year in her father's captivity, but his father did not believe his wife that Chandan was his daughter. He always kept asking her: 'Is she really my child? You haven't diluted the milk, have you?' (65) Her husband keeps testing her fidelity at every next moment and she tries to pass in every test. Sometimes, "he would spit in the plate while coughing and then push it towards his wife, saying, 'Eat from this plate, you have served too much vegetable. Why do you cook so much?' And she would quietly suffer the punishment for having cooked too much by swallowing the leftovers from his plate like a meek cow" (66). The inhuman treatment was forced by her husband on her. She was facing all the issues because she had a past. Which type of society would force a woman to live a in a situation like this. Why all these rules are only for women? Why they have to face all this? It's a very normal 
question which arises in every reader's mind but in those times, it was not at all easy for females. They faced a lot of problems in their day today life.

When Chandan was only two years old, her father died. Rajrajeshwari always tried to keep an eye on Chandan as she desired a better future for Chandan, a future which is far better than her past. Chandan's mother started looking for a worthy and suitable groom for her daughter because Chandan was extremely beautiful. According to Ruth Dhanraj: "Bhairavi touches on the prevailing social norms of the time - marriage as a necessary duty for parents of daughters to fulfil, especially if their child is uncommonly beautiful; the confines of caste and community and the inescapable clutches of one's fate" (The Hindu). These lines show parents' concern for their daughters' marriage as Rajrajeshwari worries for Chandan's marriage. She goes to Dharchula through Almora in search of a groom. Suddenly, one day a group of mountaineers came to Dharchula. They wanted shelter for one night from Raji because of hailstorm. Raji gave them permission to come in her house because she didn't know that this night will change her daughter's fate. Sonia is the girl among all boys in this group who sleeps with Chandan that night. Both of them were curious to know about each other and shared many things. Sonia discussed some of the things with her brother Vikram who was among the group of mountaineers. Noticing Vikram Looking at Chandan, Raji didn't like the presence of her daughter in front of boys, "Chandan, go. I have put milk on the stove. Just sit there and wait till it boils, on seeing her mother's stern expression, Chandan realized that she didn't like her presence in the midst of so many boys “(113). Raji didn't want to repeat the history of her past in her daughter's life so she tries to protect her. Raji even never let her wear churidars becau se she looks more prettier in this attire. She did not want anyone attracted towards her daughter. After 15 days of their departure, one day Sonia with her mother again visited Raji's house because Vikram had fallen in love with Chandan at first sight. Vikram's mother was also impressed with Chandan because of her simplicity and beauty. Rukmini, Vikram's mother was 
very much disappointed by her elder daughter in law named Sumita so she loved Chandan for her innocence. Chandan and Vikram got married and Chandan left her mother's home. "When she left her, her face was indeed glowing, there were no tears in her eyes, and there was no sign of any sadness at being parted from her mother" (138). It looked like Chandan was flying. Chandan was very happy with her new house but fate took a turn. When Chandan was going to Calcutta with her husband, an incident occurred which changed Chandan's entire fate. During the journey, the train stopped in the small station and four army officers got in to ruin their isolation. They start drinking and kept staring at Chandan, all of which scared her. Afterwards, they started beating Vikram, who tried to protect his wife but they tied him to a berth with a sheet.

She could hear her helpless, restrained husband groaning- had they gagged him too? Will they take his life? Even if they don't take his life, will she ever be able to show her besmirched face to him. The other human lion had just started pulling her towards himself when she leapt like thunder. If nothing else, she could try and find the door of the train in the dark. She didn't delay a second when she found the door of the speeding train. She deceived the eight hands trying to grab her and jumped (150).

Chandan was saved by an Aghori, who brought her to his Aghori ashram, where she was named Bairavi by the Guru. The ashram became a place for Chandan's transformation, where she acquired a rather carefree companion, Charan and a fearsome mentor, Maya didi. The Guru gave Chandan the task of translating new lines for him every day but she was instructed by Maya didi to show her the translated lines first. Maya didi was fond of Guru and did not wish Guru to get closer to Chandan. One day Chandan denied to explain one translation to Maya didi but was forced and after hearing the translated lines Maya didi's eyes turned red with anger. Maya didi assured her she will deal with Guru and there will be no further requirement of translation. 
Maya didi told her: "It is the nature of a man; he may try hard to tame it but it is that of a street dog! Put a bone in front of it and no matter how well - trained it is, it will start salivating!" (164) Maya didi told her about Delhi's Ashram and told her to go there. However, Maya didi died suddenly due to a stroke. The words of Maya reminded Bhairavi again and again "Run away, Bhairavi, far, very far" (173). When the Guru went for Maya didi's crimination he bolted the room from outside so that Bhairavi couldn't escape. Here too, she was troubled by the factors of her beauty, there was no Sanyashin who wanted to take her in. Every guru would get attracted to her and start giving undue importance to her just because of her beauty. So, her beauty itself became a curse for her, and it became the only reason for her suffering. The psychological trauma that a girl undergoes after physical assault and the social reaction to such incidents is genuinely expressed by the author:

He had made her a prisoner! She opened the window and looked outside. She hesitated once after checking the height she would have to climb down, then she tied one end of Maya Didi's sari to a nail and the other to her waist and slithered down like a wild cat. The same sari that had pulled her from death, had now given her freedom. (174)

She escaped and reached the mazaar running. She saw something miraculous there which felt as her God's presence and She prayered silently and smiled with confidence. She boarded the ladies' compartment in train and recalled the time with her husband in train. When she reached the last station, she met Maya didi's friend Vishnupriya didi and went to her ashram after Vishnupriya didi heard Maya didi's end. Vishnupriya didi asked her:

So now, where will you go, Bhairavi?' This jolted Chandan out of her sad reverie; she was not prepared for such a question. Vishnupriya did not have the courage to keep this spark of beauty in her arsenal. Ashram owner's wife Raniji's young nephew visited her often with his friends. Even her guru came on visits. She thought the one, whose divine 
beauty had swayed Maya's learned master could just as well make her old guru dream of the hues of happiness. Vishnupriya had brought her in the ashram thinking that a ordinary student of Maya didi had come to visit Delhi but she didn't find Bhairavi ordinary. Bhairavi therefore took leave from Vishnupriya didi who warned her "oh Ma! Where will you go in this new city? That too with this face. Here, even old Vaishnavis are harassed by louts and you...? Chandan stopped her mid-sentence, laughed and said, don't worry about my face, Priya di. I have learnt to hide it well" (181).

She Changed her sari in the form of Burqa. She told with confidence 'now who will know it whether it is a Sanyasi or Sanyasini'. She went to the bus stop thinking that the way of her husband's house is still for her or not. She missed her husband and coincidently her husband saw her at the station. The pray of Majar was fulfilled and her husband started kissing his wife, his companion madly. She tried to make herself free from him, which eventually happened with her mother-in-law calling Vikram to inform him about the birth of his son. Vikram had remarried to a girl named Darshan. After hearing this news, Chandan left and remembered Maya di's statement "Any man can forgive all your sins at just the sight of your face and he after all is your lusting husband" (187).

So, where she would go now? What was her fault? Was her beauty being the only thing responsible for her ill fate? Should she return to her mother's home? There are many more questions which come into readers mind after reading this novel. This novel ends at the phase of loneliness. She is all alone in this world. Women are marginalized in the society is true in this sense and beautifully brought out by the author because Chandan and her mother, both are marginalized in their own way. 


\section{References}

Dhanraj, Ruth. "Bhairavi by author Shivani is in English." The Hindu, 07 Dec. 2020, www.thehindu.com/books/bhairavi-by-hindi-author-shivani-now-available-inenglish/article33270754.ece

Dimri, Jaiwanti. Images and Representation of the Rural Women: A Study of the Selected Novels of Indian Women Writers, IIAS, 2012.

Pant, Gaura. Bhairavi: The Runaway. Translated by Priyanka Sarkar. Simon \& Schuster, 2020.

Pande, Mrinal. Forward. Bhairavi: The Runaway, Sarkar, Priyanka, Simon \& Schuster,2020, pp. X. 